\title{
The PCC assay can be used to predict radiosensitivity in biopsy cultures irradiated with different types of radiation
}

\author{
MASAO SUZUKI ${ }^{1}$, CHIZURU TSURUOKA ${ }^{1}$, TAKASHI NAKANO ${ }^{2,3}$, TATSUYA OHNO ${ }^{2}$, \\ YOSHIYA FURUSAWA ${ }^{1}$ and RYUICHI OKAYASU ${ }^{1}$ \\ ${ }^{1}$ Heavy-ion Radiobiology Research Group, ${ }^{2}$ Division of Radiation Medicine, National Institute of Radiological Sciences, \\ 4-9-1 Anagawa, Chiba 263; ${ }^{3}$ Department of Radiology and Radiation Oncology, Gunma University \\ School of Medicine, 3-39-22 Showa-machi, Maebashi, Gunma, Japan
}

Received April 26, 2006; Accepted May 17, 2006

\begin{abstract}
The aim of this study was to identify potential biomarkers for radiosensitivity using the relationship between cell killing and the yield of excess chromatin fragments detected with the premature chromosome condensation (PCC) technique. This method was applied to primary cultured cells obtained from biopsies from patients. Six primary culture biopsies were obtained from 6 patients with carcinoma of the cervix before starting radiotherapy. The cultures were irradiated with two different LET carbon-ion beams $($ LET $=13 \mathrm{keV} / \mu \mathrm{m}$, $77.1 \pm 2.8 \mathrm{keV} / \mu \mathrm{m})$ and $200 \mathrm{kV}$ X-rays. The carbon-ion beams were produced by Heavy Ion Medical Accelerator in Chiba (HIMAC). PCC was performed using the polyethylene glycolmediated cell fusion technique. The yield of excess chromatin fragments were measured by counting the number of unrejoined chromatin fragments detected with the PCC technique after a 24-h post-irradiation incubation period. Obtained results indicated that cultures which were more sensitive to killing were also more susceptible to the induction of excess chromatin fragments. Furthermore there was a good correlation between cell killing and excess chromatin fragments among the 6 cell cultures examined. There is also evidence that the induction of excess chromatin fragments increased with increasing LET as well as cell-killing effect in the same cell culture. The data reported here support the idea that the yield of excess chromatin fragments detected with the PCC technique might be useful for predicting the radiosensitivity of cells contained in tumor tissue, and to predict responses to different radiation types.
\end{abstract}

Correspondence to: Dr Masao Suzuki, Research Center for Charged Particle Therapy, National Institute of Radiological Sciences, 4-9-1 Anagawa, Chiba 263, Japan

E-mail:m_suzuki@nirs.go.jp

Key words: primary cultures, biopsy, $\mathrm{G}_{1} / \mathrm{G}_{0}$ premature chromosome condensation, carbon-ion beams, high linear energy transfer

\section{Introduction}

Carbon-ion beam radiotherapy has been used to treat cancer patients since 1994 at the National Institute of Radiological Sciences in Japan. It was realized early that it is very important to know which types of cancer were suitable for heavy-ion radiotherapy before beginning treatment. If an individual patient's radiosensitivity could be determined before treatment, heavy-ion radiotherapy could be used more effectively, and treatments could be designed for individuals. The goal of this study was to predict the radiosensitivity of individual tumors from different patients using a simple, rapid and highly sensitive biological end-point rather than cell biology methods, such as a colony-forming assay. A colony-forming assay requires time for colonies to form in culture, and the assay considers only cells which are capable of reproducing. However, in general most of the cells in a tissue may not be capable of reproduction. Chromosome aberrations in metaphase spreads are another useful method to predict cellular radiosensitivity, but these aberrations may not be always the same or comparable when cells are exposed to different types of radiation with different LET values $(1,2)$.

Another method capable of detecting radiation-induced damage at the chromosomal level is the premature chromosome condensation (PCC) technique. Several methods are available to induce PCC, such as cell fusion-mediated and drug-induced methods. The former is carried out to transfer the maturation promoting factors of M-phase cells to interphase target cells mediating cell fusion methods, such as using Sendai virus, polyethyleneglycol and electrofusion. The latter is carried out to use specific inhibitor of types 1 and 2A protein phosphatase, such as okadaic acid and calyculin A. The PCC technique is a very powerful method for detecting chromatin damage in $\mathrm{G}_{1}$ - or $\mathrm{G}_{2}$-phase cells. It is also a very useful method for comparing responses to different radiation types, such as heavy ions and X-rays, because it overcomes a difficulty encountered when using conventional chromosome analysis in mitosis. Results found with conventional analysis are affected by different radiobiological responses caused by different types of radiation, such as cell cycle delay or interphase cell death $(1,2)$. Induction of chromatin damage detected by the PCC technique in cells irradiated with either low- or high-LET 
Table I. Information on the donors.

\begin{tabular}{|c|c|c|c|c|c|c|c|}
\hline Cell & Age of donor & Primary site & Stage & Histology & Treatment & Control of primary site & Prognosis \\
\hline Cell-1 & 48 & Uterine cervix & $\mathrm{IVb}$ & $\mathrm{Sq}^{\mathrm{a}}$ & Radiotherapy alone & Controlled & $13 \mathrm{mo} \mathrm{DOD}^{\mathrm{c}}$ \\
\hline Cell-2 & 48 & Uterine cervix & $\mathrm{IIIb}$ & $\mathrm{Sq}$ & Radiotherapy alone & Controlled & 98 mo. NED ${ }^{d}$ \\
\hline Cell-3 & 43 & Uterine cervix & Ib2 & $\mathrm{Ad}^{\mathrm{b}}$ & Radiotherapy alone & Controlled & 98 mo. NED \\
\hline Cell-4 & 64 & Uterine cervix & $\mathrm{IIb}$ & $\mathrm{Ad}$ & Radiotherapy alone & Controlled & 66 mo. DOD \\
\hline Cell-5 & 71 & Uterine cervix & IVa & $\mathrm{Sq}$ & Radiotherapy alone & Recurred & 28 mo. DOD \\
\hline Cell-6 & 56 & Uterine cervix & IIIb & $\mathrm{Sq}$ & Radiotherapy alone & Controlled & 17 mo. DOD \\
\hline
\end{tabular}

${ }^{\mathrm{a} S q}$, squamous cell carcinoma; ${ }^{\mathrm{b}} \mathrm{Ad}$, adenocarcinoma; ${ }^{\mathrm{C} N E D}$, no evidence of disease; ${ }^{\mathrm{d} D O D}$, dead of disease; mo., months.

radiation shows a linear dose response in the same dose range used for cell-survival experiments (3-10). Most of the induced chromatin breaks were rejoined within a few hours after irradiation (7,9,11-13), and radiation-induced unrejoined chromatin breaks in mammalian cells correlate well with cell killing $(5,10,14-18)$. In previous studies, a good correlation was demonstrated between cell killing and unrejoined chromatin breaks observed with PCC using 6 different human cell lines irradiated with different radiation types, such as carbon-ion beams and X-rays (19). Developing from this study, the relationship between cell killing and excess chromatin fragments detected with PCC was examined in biopsy cultures in the study described here. Primary cultures, which were obtained by biopsy from 6 patients with carcinoma of the cervix, were exposed to different radiation types, such as carbon ions and X-rays, and the results suggest that this method might provide a reliable biological marker to determine individual intrinsic radiosensitivity. Such data may permit the prediction of patient radiosensitivity by using PCC to observe the number of excess chromatin fragments induced in biopsy culture (19).

\section{Materials and methods}

Cells. Six primary cultures were established from uterine cervix of 6 cervical carcinoma patients (Table I) by biopsy and were utilized in this study. Patients were properly informed and provided their consent. Punch biopsies $(5 \mathrm{~mm})$ were placed in phosphate-buffered saline (PBS) immediately after removal from patients. The biopsies were then decontaminated by a brief treatment in $70 \%$ ethanol and minced into small fragments in a plastic dish (BD Falcon ${ }^{\mathrm{TM}}$, 353003), and were incubated with $0.2 \%$ trypsin in a polypropylene tube (BD Falcon ${ }^{\mathrm{TM}}$, 352059 ) for $5 \mathrm{~min}$ at $37^{\circ} \mathrm{C}$. Eagle's minimum essential medium (MEM) supplemented with $10 \%$ fetal bovine serum and kanamycin $(60 \mathrm{mg} / \mathrm{l})$ was added to inactivate the trypsin, and the cells were washed twice with PBS. The cell suspension was inoculated into a $75-\mathrm{cm}^{2}$ plastic culture flask (BD Falcon ${ }^{\mathrm{TM}}$, 35313135 ) and cultured in MEM in a $5 \% \mathrm{CO}_{2}$ incubator at $37^{\circ} \mathrm{C}$. This cell population was labeled as passage 0 and subcultured twice in $75-\mathrm{cm}^{2}$ plastic culture flasks at a density of $1 \times 10^{6}$ cells per flask. The expanded stock culture was frozen in liquid nitrogen until use (passage 2). Freshly thawed cells were sub-cultured once and then cells at passage 4 were used for experiments. The modal chromosome number was stably maintained in culture. The number of chromosomes (average \pm standard deviation) in each culture at passage 4 was $44.0 \pm 1.7$ for Cell-1, 47.2 \pm 2.2 for Cell-2, 47.3 \pm 2.4 for Cell-3, 46.8 \pm 2.3

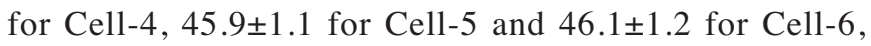
respectively. These cell cultures displayed a fibroblast-like morphology when examined under the microscope. Mitotic XP2OS (SV40 transformed) cells, which were established from Xeroderma pigmentosum complementation group A cells, and which were obtained from the Japanese Cancer Research Resources Bank (Cell line no. JCRB0301), were used as PCC inducers (19). The cells were cultured in Eagle's minimum essential medium (MEM) supplemented with $10 \%$ fetal bovine serum and kanamycin $(60 \mathrm{mg} / \mathrm{l})$ in a $5 \% \mathrm{CO}_{2}$ incubator at $37^{\circ} \mathrm{C}$.

Irradiation. Carbon-ion beam irradiation was performed as previously reported (20-23). Briefly, each culture was inoculated into $25-\mathrm{cm}^{2}$ plastic flasks (BD Falcon ${ }^{\mathrm{TM}}$, 353014) for 3 days before irradiation, by which time the cells were confluent. Cells were irradiated with carbon-ion beams generated by the HIMAC accelerator at the National Institute of Radiological sciences (NIRS) in Japan. The initial energy of the carbon-ion beams was $290 \mathrm{MeV} / \mathrm{n}$. The energy at the irradiation site was obtained by comparing the calculated and measured depth-dose distribution. The experimental dose distributions were measured with a small parallel-plate ionization chamber placed at the irradiation site (21). Two different beams with different LET values were used with Lucite absorbers of thicknesses to change the energy of the beams. At the sample position, it was estimated that the LET $\infty$ values (dose averaged LET) of all experiments was $13.3 \mathrm{keV} / \mu \mathrm{m}$ for lower LET value and $77.1 \pm 2.8 \mathrm{keV} / \mu \mathrm{m}$ for higher LET value (the mean value \pm the standard error). The absorber of $28.5 \pm 0.1 \mathrm{~mm}$ in thickness was used for making a higher LET value. The dose rate of both LET beams was approximately $1.2 \mathrm{~Gy} / \mathrm{min}$. For comparison, $200 \mathrm{kV}$ X-rays were used at a dose rate of $0.9 \mathrm{~Gy} / \mathrm{min}$. All of the irradiations were carried out at room temperature.

Clonogenic cell-survival assay. After irradiation, cells were immediately plated onto $100-\mathrm{mm}$ plastic dishes (BD Falcon ${ }^{\mathrm{TM}}$, 353003 ) at a density which permitted the formation of 60-70 viable colonies per dish. Colonies were fixed with $100 \%$ ethanol and stained with a 5\% Giemsa solution (Wako Pure Chemical Industries Ltd.) after a 14-day incubation period. Colonies consisting of more than 50 cells were scored as a 


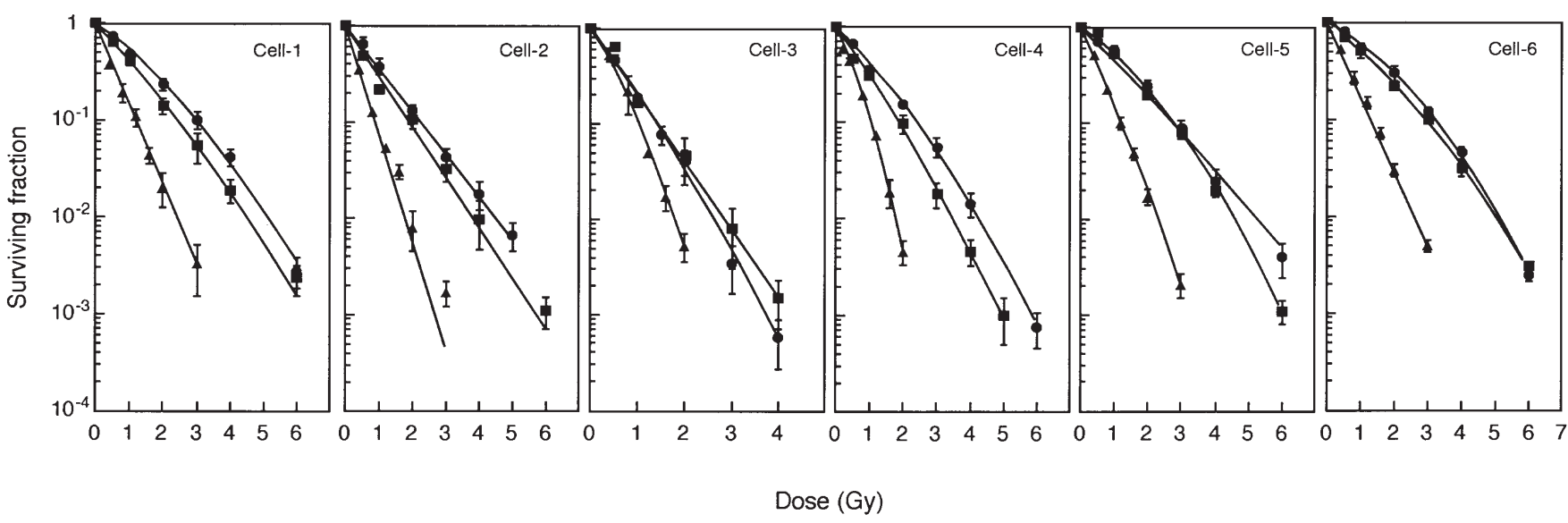

Figure 1. Dose-response survival curves for 6 cultures obtained by biopsy from 6 patients with carcinoma of the cervix irradiated with $200 \mathrm{kV}$ X-rays (closed circle); low-LET (closed square, $13.3 \mathrm{keV} / \mu \mathrm{m}$ ) and high-LET (closed triangle, $\sim 77 \mathrm{keV} / \mu \mathrm{m}$ ) carbon-ion beams. The curves were fitted with the least squares method to a linear quadratic equation, and the results shown are the mean and standard errors of at least three independent experiments.

Table II. Summary of radiobiological parameters for cell killing.

\begin{tabular}{|c|c|c|c|c|c|c|c|c|c|}
\hline \multirow[b]{2}{*}{ Cell } & \multicolumn{3}{|c|}{ X-ray (200 kV) } & \multicolumn{3}{|c|}{$\mathrm{C}$ ion $(13.3 \mathrm{keV} / \mu \mathrm{m})$} & \multicolumn{3}{|c|}{$\mathrm{C}$ ion $(\sim 77 \mathrm{keV} / \mu \mathrm{m})$} \\
\hline & $\alpha\left(\mathrm{Gy}^{-1}\right)$ & $\beta\left(\mathrm{Gy}^{-2}\right)$ & $\mathrm{D}_{10}(\mathrm{~Gy})$ & $\alpha\left(\mathrm{Gy}^{-1}\right)$ & $B\left(\mathrm{~Gy}^{-2}\right)$ & $\mathrm{D}_{10}(\mathrm{~Gy})$ & $\alpha\left(\mathrm{Gy}^{-1}\right)$ & $ß\left(\mathrm{~Gy}^{-2}\right)$ & $\mathrm{D}_{10}(\mathrm{~Gy})$ \\
\hline Cell-1 & $0.5664 \pm 0.0003$ & $0.06783 \pm 0.001$ & $2.99 \pm 0.02$ & $0.8634 \pm 0.0024$ & $0.03781 \pm 0.0004$ & $2.41 \pm 0.01$ & $1.919 \pm 0.055$ & $0.00023 \pm 0.0001$ & $1.20 \pm 0.05$ \\
\hline Cell-2 & $1.027 \pm 0.0013$ & $-0.00459 \pm 0.0015$ & $2.27 \pm 0.02$ & $1.216 \pm 0.0038$ & $-0.01442 \pm 0.0022$ & $1.94 \pm 0.02$ & $2.605 \pm 0.062$ & $-0.1568 \pm 0.0028$ & $0.94 \pm 0.04$ \\
\hline Cell-3 & $1.518 \pm 0.032$ & $0.09324 \pm 0.0042$ & $1.40 \pm 0.04$ & $1.519 \pm 0.0086$ & $0.02725 \pm 0.0007$ & $1.48 \pm 0.11$ & $1.772 \pm 0.0056$ & $0.4489 \pm 0.0049$ & $1.03 \pm 0.01$ \\
\hline Cell-4 & $0.8004 \pm 0.0053$ & $0.06586 \pm 0.0004$ & $2.40 \pm 0.02$ & $1.153 \pm 0.0056$ & $0.04673 \pm 0.0007$ & $1.86 \pm 0.02$ & $1.687 \pm 0.0012$ & $0.4936 \pm 0.0047$ & $1.05 \pm 0.003$ \\
\hline Cell-5 & $0.7931 \pm 0.0041$ & $0.01502 \pm 0.0003$ & $2.76 \pm 0.02$ & $0.5437 \pm 0.0008$ & $0.09967 \pm 0.0005$ & $2.80 \pm 0.01$ & $1.789 \pm 0.0043$ & $0.09172 \pm 0.0036$ & $1.21 \pm 0.01$ \\
\hline Cell-6 & $0.4017 \pm 0.00036$ & $0.09870 \pm 0.0002$ & $3.21 \pm 0.004$ & $0.6102 \pm 0.0005$ & $0.06175 \pm 0.0002$ & $2.91 \pm 0.002$ & $1.541 \pm 0.0016$ & $0.07996 \pm 0.0006$ & $1.39 \pm 0.003$ \\
\hline
\end{tabular}

surviving colony. The plating efficiency of the 6 cell types ranged from 15 to $40 \%$ under the experimental conditions used.

Detection of chromatin breaks in $G_{I} / G_{0}$ using PCC. The experimental method used for the detection of excess chromatin fragments in $G_{1} / G_{0}$ cells with PCC was used as previously reported (19). Briefly, irradiated cells were incubated for $24 \mathrm{~h}$ in a $5 \% \mathrm{CO}_{2}$ incubator to allow rejoining of induced chromatin breaks. Unrejoined chromatin fragments were scored as fragments remaining in $\mathrm{G}_{1} / \mathrm{G}_{0}$ cells with PCC. Mitotic XP2OS cells, accumulated after a 6 -h incubation period in the presence of $0.1 \mu \mathrm{g} / \mathrm{ml}$ demecolchicine (Wako Pure Chemical Industries Ltd.), were mixed with an equal number $\left(1 \times 10^{6}\right)$ of irradiated cells in a polypropylene tube (BD Falcon $\left.{ }^{\mathrm{TM}}, 352059\right)$ and incubated with $0.15 \mathrm{ml}$ of $50 \%(\mathrm{w} / \mathrm{v})$ polyethyleneglycol (PEG; M.W.=1540, cat. no. 783641, Roche Diagnostics $\mathrm{GmbH}$, Germany) in $75 \mathrm{mM}$ Hepes for 1 min for cell fusion. Fused cells were resuspended in $5 \mathrm{ml}$ of complete medium containing $0.1 \mu \mathrm{g} / \mathrm{ml}$ demecolchicine, and incubated in a $\mathrm{CO}_{2}$ incubator for $1 \mathrm{~h}$. These cells were subsequently treated with a $75-\mathrm{mM} \mathrm{KCl}$ solution for $20 \mathrm{~min}$ at room temperature, and fixed in 3:1 methanol:acetic acid. The cell suspension was dropped onto slides, air dried and stained with a 5\% Giemsa solution. PCC preparations of $50 \mathrm{G}_{1} / \mathrm{G}_{0}$ phase cells were scored under a light microscope. The yield of induced excess chromatin fragments per cell was estimated to be the number of remaining chromatin fragments after a 24-h post-irradiation incubation period in excess of the number of chromatin fragments found in the non-irradiated cells.

\section{Results}

Dose-response curves using a clonogenic cell-survival assay are shown in Fig. 1. These results indicate that cultures, which were sensitive to X-rays, were similarly sensitive to both lowand high-LET carbon-ion beams. Based on the survival curves, parameters for cellular radiosensitivity, such as $\alpha, \beta$ and $D_{10}$ values, were calculated using the linear-quadratic model (Table II). The RBE values listed in Table III relative to $200 \mathrm{kV}$ X-rays ranged from 0.96 to 1.29 for the low-LET beam, and 1.36-2.49 for the high-LET beam. Notably the RBE of both Cell-3 and Cell-5 cells for the low-LET beam was below 1 at the $10 \%$ survival level.

Fig. 2 shows the dose-response curves for the induction of excess chromatin fragments after a 24-h post-irradiation incubation period. Linear dose-responses were observed for each cell culture and each radiation type in the dose range used. The most sensitive cell line, Cell-3, with the cell survival assay showed the highest frequency of the induction of excess 
Table III. Summary of RBE values for cell-killing effect and induction of excess PCC fragments per Gy per cell relative to $200 \mathrm{kV}$ X-rays.

\begin{tabular}{lccccc}
\hline & \multicolumn{2}{c}{ C ion $(13.3 \mathrm{keV} / \mu \mathrm{m})$} & & \multicolumn{2}{c}{$\mathrm{C}$ ion $(\sim 77 \mathrm{keV} / \mu \mathrm{m})$} \\
\cline { 6 - 6 } \cline { 5 - 6 } Cell & $\begin{array}{c}\text { Cell } \\
\text { killing }^{\mathrm{a}}\end{array}$ & $\begin{array}{c}\text { Excess PCC } \\
\text { fragment }^{\mathrm{b}}\end{array}$ & & $\begin{array}{c}\text { Cell } \\
\text { killing }\end{array}$ & $\begin{array}{c}\text { Excess PCC } \\
\text { fragment }\end{array}$ \\
\hline Cell-1 & 1.24 & 1.97 & & 2.49 & 4.12 \\
Cell-2 & 1.17 & 1.80 & & 2.41 & 4.13 \\
Cell-3 & 0.96 & 1.85 & & 1.36 & 3.95 \\
Cell-4 & 1.29 & 1.78 & & 2.29 & 3.65 \\
Cell-5 & 0.99 & 2.06 & & 2.28 & 4.21 \\
Cell-6 & 1.10 & 1.98 & & 2.31 & 4.33 \\
\hline
\end{tabular}

${ }^{\text {aRBE }}$ was calculated using $\mathrm{D}_{10}$ values (Gy). ${ }^{\mathrm{b}} \mathrm{RBE}$ was calculated using the number of excess PCC fragments/Gy/cell.

chromatin fragments among the 6 cell cultures examined after exposure to either X-rays or carbon ions. The number of excess chromatin fragments observed per Gy for X-rays, the low-LET beam, and the high-LET beam were 1.50, 2.95 and 6.18 for Cell-1; 1.78, 3.21 and 7.36 for Cell-2; 1.99, 3.68 and 7.86 for Cell-3; 1.84, 3.28 and 6.72 for Cell-4; 1.41, 2.90 and 5.94 for Cell-5; and 1.39, 2.71 and 6.02 for Cell-6, respectively. RBE values calculated using the number of excess PCC breaks per Gy per cell relative to $200 \mathrm{kV}$ X-rays are listed in Table III.

To clarify the relationship between radiosensitivity and excess chromatin fragments, the $\mathrm{D}_{10}$ values for cell survival were plotted against the number of excess chromatin fragments per cell per Gy in Fig. 3. Data from a previous study using human cell lines (19) was plotted in Fig. 3 , and the $D_{10}$ values of the 6 cultures established from 6 cervical carcinoma patients biopsies plotted on this curve also correlated well with the number of excess chromatin fragments in each radiation, such as X-rays $(r=0.8606)$, low-LET beams $(r=0.9183)$ and highLET beams $(\mathrm{r}=0.8625)$, in the same manner as the human cell lines did.

\section{Discussion}

The PCC technique is a very powerful method for detecting chromatin damage in $\mathrm{G}_{1}$ - or $\mathrm{G}_{2}$-phase cells. Notably, it offers a very useful comparison for responses to different radiation types, such as heavy ions and X-rays, because it can overcome the difficulty involved with conventional chromosome analysis in metaphase spreads. The conventional method is affected by the differences in LET-dependent and/or dosedependent radiobiological effects produced by the different qualities of radiation, and these effects are seen as either cell cycle delays or interphase cell death (24-31). Consequently, it may be possible to underestimate the extent of chromosome damage produced by different radiation types by scoring with a single fixed sampling time using conventional analysis of metaphase spreads and not the PCC technique $(1,2)$. CocoMartin et al (32) demonstrated a good correlation between cell survival and the total number of chromosome aberrations detected with conventional metaphase analysis and also they suggested that combining doses markedly improved the correlation between cell survival and chromosome aberration yield. On the contrary several reports have shown that cellkilling effects did not always correlate well with the chromosome aberrations detected with conventional cytogenetic methods, especially when comparing responses after exposure to different types of radiation $(1,2,33)$. However, investigations using the PCC technique to measure chromosomal breaks produced by low- and high-LET radiation also indicate that there is a linear dose response in the same dose range used for cell-survival experiments with different in vitro cell systems $(3-10,18,19)$. Pantelias and Maillie (14) examined the in vitro dose-response curve of human blood mononuclear cells exposed to X-rays using the PCC technique as a biological dosimeter and found that it could be an effective system.

Several reports have shown that the number of excess chromatin fragments detected using the PCC technique in cells exposed to high-LET radiation was higher than that seen in cells exposed to low-LET radiation. Thus there was an LETdependent pattern $(5,7,9,10,18)$. In previous studies using normal human cells, approximately $95 \%$ of ${ }^{137} \mathrm{Cs}-\gamma$-ray induced PCC breaks were rejoined, while only $50 \%$ of $110 \mathrm{keV} / \mu \mathrm{m}-$ or $124 \mathrm{keV} / \mu \mathrm{m}$-carbon-ion induced PCC breaks were rejoined
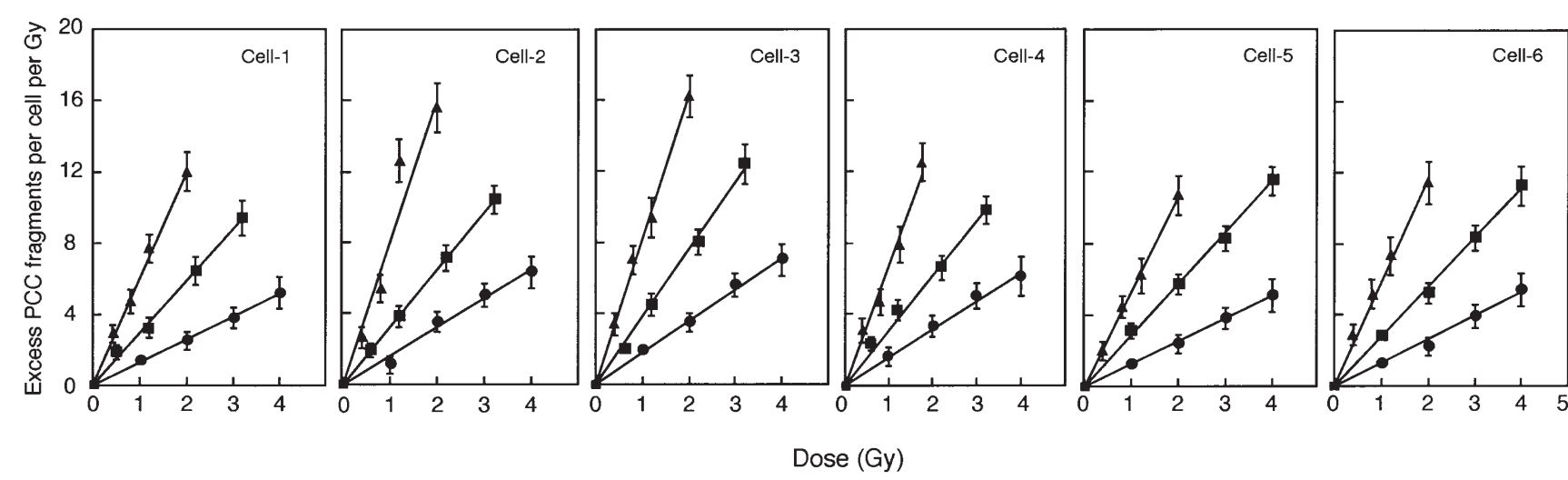

Dose (Gy)

Figure 2. Dose-response curves for the production of excess chromatin fragments after $24 \mathrm{~h}$ of post-irradiation incubation following irradiation with $200 \mathrm{kV}$ $\mathrm{X}$-rays (closed circle) or low-LET (closed square, $13.3 \mathrm{keV} / \mu \mathrm{m}$ ) and high-LET (closed triangle, $\sim 77 \mathrm{keV} / \mu \mathrm{m}$ ) carbon-ion beams. The curves were fitted with the least squares method, and the results show the mean and standard errors of at least three independent experiments. 

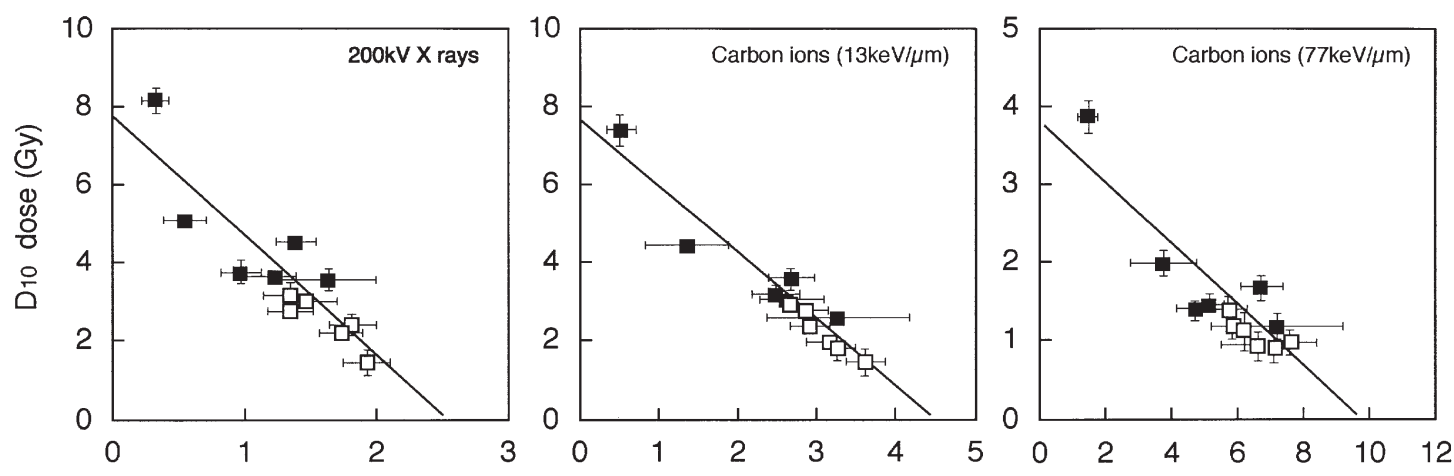

Excess PCC fragments / Gy / cell

Figure 3. Relationship between $D_{10}$ values and the number of excess chromatin fragments per Gy per cell for each radiation type in 6 different human cell lines (closed square) and 6 cultures obtained by biopsy from 6 patients (open square). The data for human cell lines was taken from Suzuki et al (19). The curve was generated from the data for 6 cell lines reported in Suzuki et al (19).
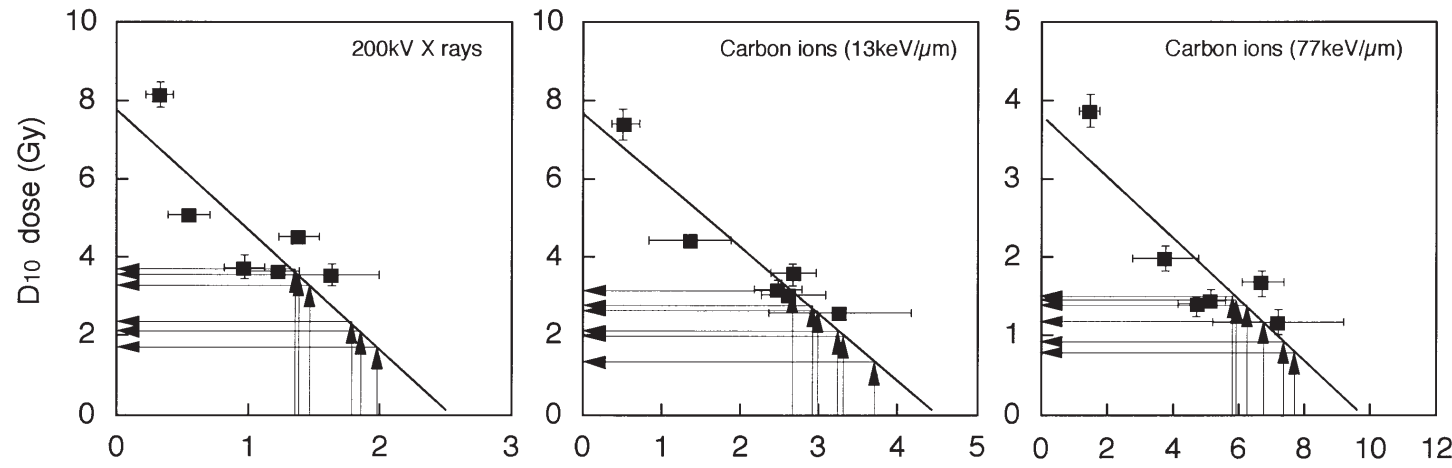

Excess PCC fragments / Gy / cell

Figure 4. Estimation of $D_{10}$ values for cell survival in cultures was obtained from biopsies from 6 patients using the data for excess chromatin fragments. The data for the number of excess fragments was used to read the $\mathrm{D}_{10}$ value from the $\mathrm{Y}$ axis by using the standard curve generated in Fig. 3 from cell line data (Suzuki et al) and plotted here.

after a 24-h post-irradiation incubation period (10). The percent of unrejoined breaks varied ranging from 23 to $50 \%$, depending on the LET value of the carbon-ion beam, which ranged from 22 to $230 \mathrm{keV} / \mu \mathrm{m}$ (10). Some studies have also indicated that the radiosensitivity of human tumor-cell lines or normal human cells after exposure to low-LET photons and high-LET radiation correlated well with the number of excess chromatin fragments $(5,10,15-18,34-36)$ as well as with the induction of non-repaired DNA double-strand breaks (35,37-43). However, as pointed out in the report by Dikomey et al (42), the radiation doses required to detect DNA strand breaks ( $90 \mathrm{~Gy})$ were much higher than those necessary to observe cell-killing (up to $9 \mathrm{~Gy}$ ), while cytogenetic studies using the PCC technique could be completed within a dose range similar to that used for cell-killing studies. This defines another advantage for the PCC technique: it is possible to compare these different biological end-points (cell killing and PCC breaks) in a similar radiation dose range.

In a previous study, a close relationship was demonstrated between cell-killing effects and the number of excess chromatin fragments measured with $\mathrm{G}_{1} / \mathrm{G}_{0}$ PCC in 6 different human cell lines irradiated with different types of radiation, such as $\mathrm{X}$-rays and carbon ions (19). The $\mathrm{D}_{10}$ values of 6 cultures established from 6 cervical carcinoma patient biopsies also correlated well with the number of excess chromatin fragments in a similar manner (Fig. 3). Because it will often be impossible to obtain radiosensitivity data for each individual patient using clonogenic cell-survival assays from a piece of tissue obtained from a tumor biopsy, it would be useful to be able to predict individual radiosensitivities using some other biomarker. In the present study, an attempt was made to estimate cellular radiosensitivity from cultures from 6 cervical carcinoma patient biopsies, and to compare this to the number of excess PCC fragments per Gy per cell found in each culture. To make this correlation, $\mathrm{D}_{10}$ values were plotted on the vertical axis and the number of excess PCC fragments per Gy per cell was plotted on the horizontal axis in Fig. 3. This data was obtained from cell lines (19). In this plot it was possible to determine the relationship between these two parameters experimentally. In Fig. 4, the same parameters were plotted and the line from Fig. 3 generated from the cell line data was added. Using this graph, the number of excess PCC fragments per Gy per cell 
Table IV. Comparison of $\mathrm{D}_{10}$ values obtained directly from survival curves and PCC data using 6 cultures irradiated with $\mathrm{X}$-rays and carbon-ion beams.

$$
\mathrm{D}_{10} \text { values (Gy) }
$$

( $\mathrm{D}_{10}$ from survival curve/ $\mathrm{D}_{10}$ estimated by PCC data)

\begin{tabular}{lccccr}
\cline { 2 - 6 } Cell & $\begin{array}{c}\text { X-rays } \\
(\text { error \%) }\end{array}$ & $\begin{array}{c}\text { Carbon ions } \\
(\text { error \% }) \\
(13 \mathrm{keV} / \mu \mathrm{m})\end{array}$ & \multicolumn{2}{c}{$\begin{array}{c}\text { Carbon ions } \\
(\text { error \%) } \\
(\sim 77 \mathrm{keV} / \mu \mathrm{m})\end{array}$} \\
\hline Cell-1 & $2.99 / 3.2$ & $(7.0)$ & $2.41 / 2.6(7.9)$ & $1.20 / 1.3$ & $(8.3)$ \\
Cell-2 & $2.27 / 2.3$ & $(1.3)$ & $1.94 / 2.1(8.2)$ & $0.94 / 0.92$ & $(2.1)$ \\
Cell-3 & $1.40 / 1.6(14.3)$ & $1.48 / 1.4(5.4)$ & $1.03 / 0.87$ & $(15.5)$ \\
Cell-4 & $2.40 / 2.1(12.5)$ & $1.86 / 2.0(7.5)$ & $1.03 / 1.1$ & $(6.8)$ \\
Cell-5 & $2.76 / 3.1(12.3)$ & $2.80 / 2.8(0.0)$ & $1.21 / 1.4$ & $(15.7)$ \\
Cell-6 & $3.21 / 3.5$ & $(9.0)$ & $2.91 / 3.0(3.1)$ & $1.39 / 1.5$ & $(7.9)$
\end{tabular}

$\mid\left(D_{10}\right.$ from survival curve $)-\left(D_{10}\right.$ estimated by PCC data $) \mid$

${ }^{\mathrm{a}}$ Error $(\%)=1 \times 100$

( $\mathrm{D}_{10}$ from survival curve)

on the $\mathrm{X}$ axis was used to obtain a $\mathrm{D}_{10}$ value for the biopsy samples by using the line generated by cell line data from Fig. 3 (19). The number of excess PCC fragments per Gy per cell was used to read a $\mathrm{D}_{10}$ value directly on the $\mathrm{Y}$ axis.

Fortunately, it was possible to obtain $\mathrm{D}_{10}$ values experimentally from the 6-biopsy cultures used and compare them directly with the values obtained with the PCC data and the cell line standard curve shown in Fig. 4; these are summarized in Table IV. The difference in the $\mathrm{D}_{10}$ values between the two different protocols varied from 0 to $15.7 \%$. However, we can predict the radiosensitivity of the cultures established from the 6 cervical carcinoma patient biopsies with a variation of less than $16 \%$ with this protocol.

In conclusion, several methods are available to induce PCC, such as Sendai virus-mediated cell fusion, polyethyleneglycolmediated cell fusion and drug-induced method. We tried to use Calyculin A for our cell system. Unfortunately, the fibroblastlike cells used in this study could not form $G_{1} / G_{0}$ or $G_{2}$ PCC. We examined whether Calyculin A-induced PCC was successful or not using other human cell lines. The obtained results showed that no $G_{1} / G_{0}$ or $G_{2}$ PCC was induced in fibroblasts, while $\mathrm{G}_{2}$ PCC was dominantly induced in epithelial cells. The advantages of using the PEG-mediated PCC technique to predict the radiosensitivity of tumor cells are: i) this method is useful for non-cycling/non-clonogenic cells; ii) less time is required in obtaining results than when using colony-forming assays; and iii) it is a direct measure of repair of radiation damage. It is, therefore, very useful to use this method with biopsy samples. The data obtained with the PCC technique may accurately reflect radiation damage at the chromatin level without complications arising from cell cycle delays and/or interphase cell death. This means that the PCC technique is very useful for detecting chromatin damage produced by qualitatively different radiation types, such as low- and high-LET radiation. The present data illustrate the possibility of utilizing the PCC technique as a biological assay to measure the intrinsic radiosensitivity of cells contained in tumor tissue, and as a biological fundamental study for predicting the radiosensitivity of cells for clinical radiotherapy, notably radiotherapy using high-LET heavy ions.

\section{Acknowledgements}

The authors wish to thank the staff of the HIMAC for their help with the carbon-ion beam irradiations and Dr Leon Kapp at the University of California for his critical reading of the manuscript. This study was supported in part by grants from the Japanese Ministry of Education, Science and Culture, and in part by the program for 'Ground-based Research for Space Utilization' promoted by the Japan Space Forum.

\section{References}

1. Ritter S, Nasonova E, Scholz M, Kraft-Weyrather W and Kraft G: Comparison of chromosomal damage induced by X-rays and $\mathrm{Ar}$ ions with a LET of $1840 \mathrm{keV} / \mu \mathrm{m}$ in G1 V79 cells. Int J Radiat Biol 69: 155-166, 1996.

2. Suzuki M, Nakano K, Suzuki K and Watanabe M: Influence of the sampling time on chromosomal aberrations at $\mathrm{G}_{2}$ phase in Syrian hamster embryonic cells irradiated with different types of radiation. Int J Radiat Biol 76: 815-821, 2000.

3. Pantelias GE and Maillie HD: Direct analysis of radiationinduced chromosome fragments and rings in unstimulated human peripheral blood lymphocytes by means of the premature chromosome condensation technique. Mutat Res 149: 67-72, 1985.

4. Bedford JS and Goodhead DT: Breakage of human interphase chromosomes by alpha particles and X-rays. Int J Radiat Biol 55: 211-216, 1989.

5. Goodwin E, Blakely TE, Ivery G and Tobias SC: Repair and misrepair of heavy-ion-induced chromosomal damage. Adv Space Res 9: 83-89, 1989.

6. Cornforth MN and Goodwin EH: The dose-dependent fragmentation of chromatin in human fibroblasts by $3.5-\mathrm{MeV} \alpha$ particles from ${ }^{238} \mathrm{Pu}$ : experimental and theoretical considerations pertaining to single-track effects. Radiat Res 127: 64-74, 1991.

7. Suzuki M, Watanabe M, Suzuki K, Nakano K and Matsui K: Heavy-ion induced chromosome breakage studied by premature chromosome condensation (PCC) in Syrian hamster embryo cells. Int J Radiat Biol 62: 581-586, 1992.

8. Loucas BD and Geard CR: Initial damage in human interphase chromosomes from alpha particles with linear energy transfer relevant to Radon exposure. Radiat Res 139: 9-14, 1994.

9. Goodwin EH, Blakely EA and Tobias CA: Chromosome damage and repair in $\mathrm{G}_{1}$-phase Chinese hamster ovary cells exposed to charged-particle beams. Int J Radiat Biol 138: 343-352, 1994.

10. Suzuki M, Watanabe M, Kanai T, Kase Y, Yatagai F, Kato T and Matsubara S: LET dependence of cell death, mutation induction and chromatin damage in human cells irradiated with accelerated carbon ions. Adv Space Res 18: 127-136, 1996.

11. Hittelman WN and Rao PN: Premature chromosome condensation I. Visualization of X-ray induced chromosome damage in interphase cells. Mutat Res 23: 251-258, 1974.

12. Cornforth MN and Bedford JS: X-ray-induced breakage and rejoining of human interphase chromosomes. Science 222: 1141-1143, 1983.

13. Iliakis GE and Pantelias GE: Production and repair of chromosome damage in an X-ray sensitive $\mathrm{CHO}$ mutant visualized and analyzed in interphase using the technique of premature chromosome condensation. Int J Radiat Biol 57: 1213-1223, 1990.

14. Pantelias GE and Maillie HD: The use of peripheral blood mononuclear cell prematurely condensed chromosomes for biological dosimetry. Radiat Res 99: 140-150, 1984.

15. Brown JM, Evans J and Kovacs MS: The prediction of human tumor radiosensitivity in situ: an approach using chromosome aberrations detected by fluorescence in situ hybridization. Int $\mathbf{J}$ Radiat Oncol Biol Phys 24: 279-286, 1992.

16. Pandita TK and Hittelman WN: The contribution of DNA and chromosome repair deficiencies to the radiosensitivity to AtaxiaTelangiectasia. Radiat Res 131: 214-223, 1992. 
17. Sasai K, Evans JW, Kovacs MS and Brown JM: Prediction of human cell radiosensitivity: comparison of clonogenic assay with chromosome aberrations scored using premature chromosome condensation with fluorescence in situ hybridization. Int J Radiat Oncol Biol Phys 30: 1127-1132, 1994.

18. Suzuki M, Kase Y, Kanai T, Yatagai F and Watanabe M: LET dependence of cell death and chromatin-break induction in normal human cells irradiated by neon-ion beams. Int J Radiat Biol 72: 497-503, 1997.

19. Suzuki M, Kase Y, Kanai T and Ando K: Correlation between cell killing and residual chromatin breaks measured by PCC in six human cell lines irradiated with different radiation types. Int J Radiat Biol 76: 1189-1196, 2000.

20. Suzuki M, Kase Y, Yamaguchi H, Kanai T and Ando K: Relative biological effectiveness for cell-killing effect on various human cell lines irradiated with heavy-ion medical accelerator in Chiba (HIMAC) carbon-ion beams. Int J Radiat Oncol Biol Phys 48: 241-250, 2000.

21. Kanai T, Kohno T, Minohara S, Sudoh M, Takada E, Soga F Kawachi K and Fukumura A: Dosimetry and measured differential W values of air for heavy ions. Radiat Res 135: 293-301, 1993.

22. Kanai T, Tomura H, Matsufuji N, Minohara S, Fukumura A, Hiraoka T, Furusawa Y, Miyahara N, Koyama-Itoh H, Endo M Soga F and Kawachi K: HIMAC beam delivery system physical characteristics. Proc NIRS Int Semin Applic Ther Cancer in connection with XXI PTCOG Meeting: 26-31, 1994.

23. Kanai T, Endo M, Minohara N, Miyahara N, Koyama-Ito H, Tomura H, Matsufuji N, Futami Y, Fukumura A, Hiraoka T, Furusawa Y, Ando K, Suzuki M, Soga F and Kawachi K: Biophysical characteristics of HIMAC clinical irradiation system for heavy-ion radiation therapy. Int J Radiat Oncol Biol Phys 44: 201-210, 1999

24. Lücke-Huhle C, Blakely EA, Change PY and Tobias CA: Drastic $\mathrm{G}_{2}$ arrest in mammalian cells after irradiation with heavyion beams. Radiat Res 79: 97-112, 1979.

25. Lücke-Huhle $C$ : Alpha-irradiation-induced $\mathrm{G}_{2}$ delay: a period of cell recovery. Radiat Res 89: 298-308, 1982.

26. Palayoor ST, Humm JL, Atcher RW, Hines JJ and Macklis RM: $\mathrm{G}_{2} \mathrm{M}$ arrest and apoptosis in murine T lymphoma cells following exposure to 212Bi alpha particle irradiation. Nucl Med Biol 20: 795-805, 1993.

27. Scholz M, Kraft-Weyrather W, Ritter S and Kraft G: Cell cycle delays induced by heavy ion irradiation of synchronous mammalian cells. Int J Radiat Biol 66: 59-75, 1994.

28. Sasaki H, Yatagai F, Kanai T, Furusawa Y, Hanaoka F, Zhu WG and Mehnati P: Dependence of induction of interphase death of Chinese hamster ovary cells exposed to accelerated heavy ions on linear energy transfer. Radiat Res 148: 449-454, 1997.

29. Meijer AE, Kronqvist USE, Lewensohn R and HarmsRingdahl M: RBE for the induction apoptosis in human peripheral lymphocytes exposed in vitro to high-LET radiation generated by accelerated nitrogen ions. Int J Radiat Biol 73: 169-177, 1998 .
30. Ohnishi T, Takahashi A, Yano T, Matsumoto H, Wang X, Ohnishi K, Tamamoto T, Tsuji K, Furusawa Y and Yukawa O: Hyperthermic enhancement of tumour growth inhibition by accelerated carbon-ions in transplantable human esophageal cancer. Int J Hyperthermia 14: 195-202, 1998.

31. Aoki M, Furusawa Y and Yamada T: LET dependency of heavy-ion induced apoptosis in V79 cells. J Radiat Res 41: 163-175, 2000.

32. Coco-Martin JM, Mooren E, Ottenheim C, Burrill W, Nunez MI, Sprong D, Bartelink $\mathrm{H}$ and Begg AC: Potential of radiationinduced chromosome aberrations to predict radiosensitivity in human tumour cells. Int J Radiat Biol 75: 1161-1168, 1999.

33. Griffin CS, Harvey AN and Savage JRK: Chromatid damage induced by ${ }^{238} \mathrm{Pu} \alpha$-particles in $\mathrm{G}_{2}$ and $\mathrm{S}$ phase Chinese hamster V79 cells. Int J Radiat Biol 66: 85-98, 1994

34. Kodym R and Hoerth E: Determination of the radiation sensitivity of the stromal cells in the murine long-term bone marrow culture by measuring the induction and rejoining of interphase chromosome breaks. Int J Radiat Oncol Biol Phys 25: 829-833, 1993.

35. Badie C, Iliakis G, Foray N, Alsbeih G, Chavaudra N, Pantelias G, Arlett $\mathrm{C}$ and Malaise EP: Induction and rejoining of DNA double-strand breaks and interphase chromosome breaks after exposure to $\mathrm{X}$ rays in one normal and two hypersensitive human fibroblast cell lines. Radiat Res 144: 26-35, 1995.

36. Borgmann K and Dikomey E: Relationship between PCC fragments and cell killing studied in X-irradiated $\mathrm{CHO}, \mathrm{CHO}-\mathrm{K} 1$ cells and two radiosensitive mutants xrs1 and xrs 5. Int J Radiat Biol 72: 667-674, 1997.

37. Ward JF: Mechanisms of DNA repair and their potential modification for radiotherapy. Int J Radiat Oncol Biol Phys 12 : 1027-1032, 1986.

38. Schwartz JL, Rotmensch J, Giovanazzi S, Cohen MB and Weichselbaum RR: Faster repair of DNA double-strand breaks in radioresistant human tumor cells. Int $\mathrm{J}$ Radiat Oncol Biol Phys 15: 907-912, 1988.

39. Wurm R, Burnet NG, Duggal M, Yarnold JR and Peacock JH: Cellular radiosensitivity and DNA damage in primary human fibroblasts. Int J Radiat Oncol Biol Phys 30: 625-633, 1994

40. Zaffaroni N, Orlandi L, Villa R, Bearzatto A, Rofstad EK and Silvestrini R: DNA double-strand break repair and radiation response in human primary cultures. Int J Radiat Biol 66: 279-285, 1994.

41. Whitaker SJ, Ung YC and McMillan TJ: DNA double-strand break induction and rejoining as determinants of human tumour cell radiosensitivity. A pulsed-field gel electrophoresis study. Int J Radiat Biol 67: 7-18, 1995.

42. Dikomey E, Dahm-Daphi J, Brammer I, Martensen R and Kaina B: Correlation between cellular radiosensitivity and nonrepaired double-strand breaks studied in nine mammalian cell lines. Int J Radiat Biol 73: 269-278, 1998.

43. Zhou PK, Sproston AR, Marples B, West M, Margison GP and Hendry JH: The radiosensitivity of human fibroblast cell lines correlates with residual levels of DNA double-strand breaks. Radiother Oncol 47: 271-276, 1998. 